\title{
Pertanian Perdesaan Lampung: Peluang dan Tantangan Lampung Rural Agriculture; Opportunities And Challenges
}

\author{
Fitriani $^{1)}$, Sutarni ${ }^{1)}$, Dwi Haryono ${ }^{2)}$, Hanung Ismono $^{2)}$ Dyah Aring Hepiana Lestari ${ }^{2)}$ \\ ${ }^{1}$ Staf Pengajar PS Agribisnis Politeknik Negeri Lampung \\ ${ }^{2}$ Staf Pengajar Jurusan Agribisnis Universitas Lampung \\ e-mail: *1 fitriani@polinela.ac.id
}

\begin{abstract}
The numbers of Lampung residents with average monthly expenditure per capita below the poverty line are still quite large (14.86\%). Most of the poor are in the district (76.26\%) and are rural communities dependent on the agricultural sector for their livelihoods. Rural agricultural communities face complex problems including: the limitations of land access, capital, technology, markets, and institutions. This project, conducted in 2014, was a series of research collaboration of universities (PEKERTI) between State Polytechnic of Lampung (Polinela) as Research Team Proposer (TPP) with University of Lampung (Unila) as Research Partner Team (TPM). Method of depth analysis about Lampung rural agriculture society condition during 10 years and cross tabulation were conducted based on Lampung Input Output Table 2010. The secondary data were obtained from Provincial BPS (Lampung Statistic Office) and some other related technical agencies. The results of the discussion showed that the portrait of Lampung agriculture is dominated by rural farming which faces very complex problems. The complexity of the problems within agricultural society is a resultant of the limitations faced by farmers in accessing capital, land, technology and institutional resources. This condition boils down to structural poverty. The key to the work of sustainable rural agricultural development policy is the occurrence of synergy in overcoming obstacles which include: local agro-climatic conditions, site-specific technologies, availability of biomass, economic incentives, product markets, information access, land tenure, institutional, extension, and political constraints.
\end{abstract}

Keywords: Agriculture, Poverty, Sector, Village

\section{Pendahuluan}

Pembangunan sektor pertanian adalah suatu keharusan. Sektor pertanian merupakan penghasil bahan pangan yang penting bagi masyarakat. Kedaulatan pangan sangat strategis dalam kedaulatan berbangsa dan bernegara. Oleh karenanya, sangat tepatlah bila pidato Presiden Soekarno pada kesempatan peletakan batu pertama pembangunan Institut Pertanian Bogor dengan jelas menyebutkan bahwa persoalan pangan adalah persoalan hidup dan matinya sebuah bangsa. Kemandirian dan kedaulatan pangan hanya dapat wujud apabila sektor pertanian kuat. berarti Kendala-kendala yang dihadapi sektor pertanian secara garis besar meliputi: (1) menurunnya tingkat produktivitas lahan sebagai akibat menurunnya tingkat kesuburan lahan, (2) tingginya tingkat alih fungsi lahan pertanian, (3) lahan kritis semakin luas, (4) meningkatnya pencemaran dan kerusakan lingkungan pertanian, (5) menurunnya daya dukung likungan, (6) meningkatnya tingkat pengangguran di pedesaan, (7) berkurangnya posisi daya tukar petani, (8) menurunnya penghasilan dan kesejahteraan keluarga petani, dan bermuara pada (9) meningkatnya kesenjangan antar kelompok masyarakat.

Propinsi Lampung berdiri berdasarkan UU No. 14 tahun 1964. Berarti, telah genab setengah abad kini berusaha untuk mensejajarkan diri dengan propinsi lain di Indonesia. Bagaimana kualitas pembangunan masyarakat Lampung dapat dilihat dari apaian nilai Capaian 
Indeks Pembangunan Manusia (IPM). IPM Lampung selama tiga tahun terakhir mengalami peningkatan, dari 71,42 (2010); 71,94 (2011), dan 72,45 (2012). IPM Lampung > 70 berada pada kategori menengah ke atas, berarti masyarakat Lampung telah berada pada kondisi mencapai kualitas hidup yang lebih baik. IPM adalah indikator capaian pembangunan satu wilayah, merupakan cerminan dari kondisi Angka Harapan Hidup, Angka Melek Huruf, dan rata-rata lama sekolah. Capian IPM tertinggi kabupaten/kota adalah Metro dengan nilai 77,30 dan yang terendah Mesuji 68,30. Hal ini berarti kualitas pembangunan manusia di Kota Metro adalah yang terbaik di Lampung. Meskipun, secara regional Sumatera, nilai IPM Propinsi Lampung merupakan nilai terkecil dari 10 propinsi yang ada, dengan capaian tertinggi diraih Riau (IPM 76,9).

Berdasarkan sensus tahun 2010, penduduk Propinsi Lampung sebesar 7.608.405 jiwa. Masih terdapat 1.163.060 penduduk yang memiliki rata-rata pengeluaran per kapita per bulan di bawah garis kemiskinan, atau sebesar $14,86 \%$ dari total penduduk Lampung. Persentasi penduduk miskin tersebut mengalami penurunan bila dibandingkan dengan kondisi tahun 2011 sebesar 16,93\% (1.253.830 orang). Sebagian besar penduduk miskin berada di kabupaten $(76,26 \%)$ dan merupakan masyarakat perdesaan yang bergantung pada sektor pertanian sebagai mata pencahariannya. Penduduk miskin perkotaan sebesar 24,74\%. Kabupaten Lampung Utara memiliki penduduk miskin terbesar $(25,17 \%)$, selanjutnya Lampung Timur (18,59\%), dan Pesawaran $(18,01)$.

Pertanian perdesaan minim memberikan tingkat pendapatan dan kesejahteraan yang memadai bagi masyarakatnya. Kemiskinan struktural perdesaan tidak terlepas dari terbatasnya akses masyarakat perdesaan dalam kepemilikan lahan. Kondisi ini dapat dilihat dari peningkatan Rumah Tangga Pertanian (RTP) dengan akses lahan $<0,25$ ha mengalami peningkatan $>33 \%$ dalam kurun 10 tahun terakhir (BPS, 2013).

Persoalan kompleks terkait rendahnya produktivitas, keterbatasan akses terhadap modal dan pasar, kelembagaan juga adopsi teknologi yang masih tertinggal masih dihadapi sektor pertanian rakyat di Lampung. Ketersediaan input yang terjangkau dan tersedia pada saat yang tepat masih dihadapi petani. Tidak adanya jaminan harga dan pasar menjadi hambatan petani mendapatkan pendapatan yang menguntungkan, sehingga menekan daya beli dan kesejahteraan petani terutama di perdesaan. Produk pertanian yang dihasilkan petani lokal masih harus menghadapi serbuan produk impor komoditas pangan dan hortikultura, sehingga produk petani sering terpinggirkan dan tidak mampu bersaing dalam aspek harga dan kualitas produknya;

Pertanian juga menghadapi persoalan perubahan iklim global yang menyebabkan pola tanam berubah, serangan organisme pengganggu yang menyebabkan gagal panen, hingga kekeringan dan banjir. Secara internal sumberdaya pertanian menghadapi persoalan yang lebih pelik, mengingat ketertarikan generasi muda dalam menerukan dan memulai usaha pertanian menunjukkan kecenderungan makin rendah. Petani rakyat didominasi oleh petani dengan ratarata berusia 55-60 tahun dan tidak memiliki pengetahuan dan pendidikan yang memadai. Sementara sumberdaya penunjang transfer teknologi (penyuluh pertanian) relatif masih belum memadai dengan banyaknya petani yang ada. Akibat lebih lanjut menyebabkan pendampingan dan transfer teknologi tidak dapat berjalan secara efektif dan menyebabkan petani berjuang sendiri menghadapi segala masalah yang kompleks dengan keterbatasannya. Kondisi tersebut di atas tentu dapat menyulitkan sektor pertanian, apalagi dengan kondisi menghadapi pasar bebas ASEAN.

Informasi rancangan rekomendasi kebijakan yang tepat akan menjadi simpul kunci pembangunan sektor pertanian dapat menjadi solusi munculnya dampak pengganda ekonomi bagi masyarakat melalui tumbuhnya sumber alternatif pendapatan baru, peningkatan pendapatan, sumber serapan tenaga kerja, pengurangan pengangguran dan kemiskinan, pemerataan dan pertumbuhan ekonomi wilayah. Efektivitas bekerjanya (dampak) kebijakan di sektor pertanian melalui rumusan rekomendasi kebijakan pembangunan sektor pertanian yang tepat mampu meningkatkan kesejahteraan masyarakat dan lebih adil.

Penelitian ini bertujuan untuk menggambarkan kondisi faktual pertanian perdesaan Lampung melalui potret kinerja sektor pertanian. Informasi tersebut penting sebagai entry point 
penguatan masyarakat pertanian perdesaan. Gambaran pertanian perdesaan Lampung sebagai mikrousahatani perdesaan menjadi basis penting menuju terwujudnya masyarakat bioindustri perdesaan sebagaiman tertian dalam RPJM Pembangunan Pertanian 2015-2045.

\section{Metode}

Penelitian ini merupakan penelitian kerjasama perguruan tinggi (PEKERTI) antara Politeknik Negeri Lampung dengan Universitas Lampung sebagai Perguruan Tinggi Mitra pada 2015. Data yang digunakan adalah data sekunder yang diperoleh dari kantor BPS propinsi dan pusat, serta institusi terkait. Metode statistik deskriptif dan depth analysis terhadap kondisi masyarakat pertanian perdesaan Lampung dalam kurun waktu lima tahun terakhir.

\section{Hasil dan Pembahasan}

\section{Pertanian Perdesaan Lampung}

Wilayah perdesaan meliputi $90 \%$ dari total teritori pemerintahan daerah Lampung. Pembangunan perdesaan tidak terlepas dari pembangunan pertanian secara integral. Fakta di lapang bahwa sektor pertanian menjadi sumber pendapatan bagi $48,31 \%$ pekerja di Lampung (Tabel 1) menunjukkan bahwa pertanian menjadi lokomotif penting dalam menggerakkan roda ekonomi Lampung. Sektor pertanian menjadi sumber mata pencaharian bagi 1.666 .372 tenaga kerja dari total tenaga kerja Lampung pada tahun 2013 sebesar 3.449.307 tenaga kerja. Serapan tenaga kerja berdasarkan sektor di Lampung pada Tabel 1.

Jumlah penduduk usia 15 tahun ke atas yang telah bekerja pada tahun 2014 sebanyak 3.673.158 orang. Sebanyak 1.795.206 orang bekerja di sektor pertanian, perkebunan, peternakan, kehutanan, dan perikanan. Fakta ini menunjukkan bahwa $48,87 \%$ penduduk yang bekerja merupakan tenaga kerja yang menggantungkan mata pencariannya dari sektor pertanian. Pangsa tenaga kerja pada sektor strategis dapat dilihat pada Gambar 1.

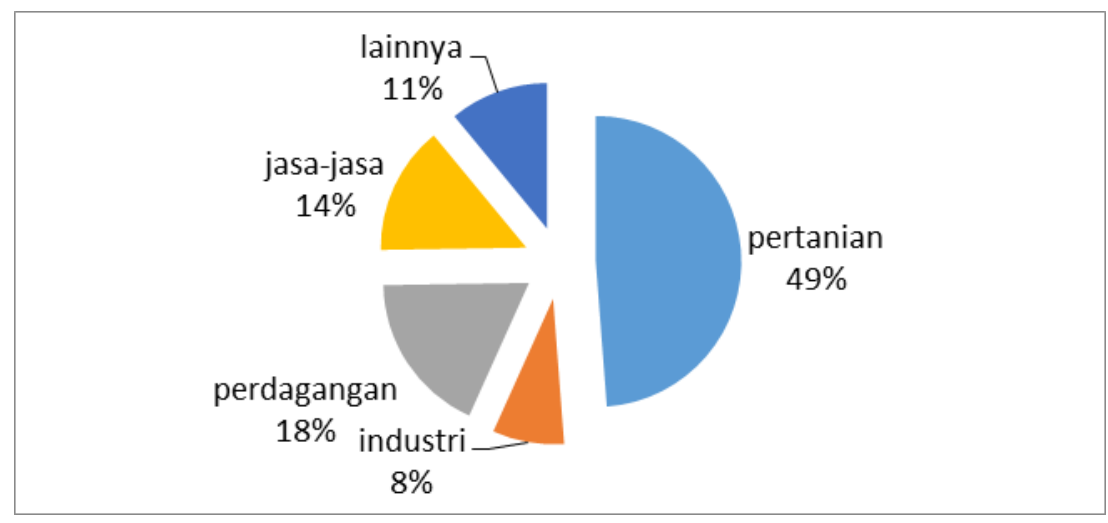

Gambar 1. Pangsa tenaga kerja pada sektor strategis di Propinsi Lampung, 2014

Sumber: BPS Propinsi Lampung, 2015

Sektor pertanian menjadi sektor strategis yang berkontribusi sebagai sumber mata pencarian utama bagi penduduk di Lampung, selanjutnya sektor jasa dan terakhir sektor industri. Sektor terbesar kedua dalam memberikan pekerjaan bagi angkatan kerja adalah sektor jasa. Sektor jasa secara luas berkembang pesat sebagai sektor strategis dalam menyediakan lapangan kerja bagi masyarakat, termasuk di dalamnya jasa perdagangan hasil pertanian. Jasa perdagangan produk pertanian berkembang seiring tuntutan kebutuhan dan peningkatan kualitas produk dan jasa pertanian. Lebih lanjut menyebabkan arus mobilitas produk pertanian raw material terjadi antarpulau dan antarnegara.

Namun mobilisasi produk pertanian dalam wujud raw material dalam arus perdagangan antar pulau dan negara menjadi ironi apabila menyebabkan masyarakat pertanian perdesaan 
tidak berkembang ke arah orientasi peningkatan nilai tambah. Kondisi tersebut menunjukkan belum berkembangnya industri pengolahan produk pertanian (agroindustri) atau bioindustri perdesaan, sehingga menyebabkan nilai tambah mengalir ke luar wilayah.

Sementara itu, pada sisi yang lain dapat dilihat bahwa, serapan tenaga kerja sektor industri paling kecil dan bahkan menunjukkan kecenderungan menurun. Kondisi ini menjelaskan bahwa sektor industry belum mampu secara optimal menjadi penyedia lapangan kerja bagi angkatan kerja di Lampung. Perkembangan sektor industri yang cenderung stagnan dan lambat dalam menyediakan lapangan kerja juga menjadi indikasi bahwa hasil produksi utama Lampung dari sektor pertanian sebagai raw material bagi agroindustri belum optimal dapat meningkatkan nilai tambah produk olahannya. Lebih lanjut, menjadi penyebab disorientasi arah pengembangan hasil pertanian ke industri sebagai muara (hilir) pengolahan produksi pertanian. Padahal agroindustri menjadi kunci peningkatan nilai tambah produk pertanian.

Namun kondisi tingkat upah tenaga kerja pertanian masih jauh tertinggal dibandingkan dengan sektor lain. Sektor pertanian seringkali dipandang sebagai sektor informal, dengan produktivitas tenaga kerja yang rendah. Akibatnya nilai tukar tingkat upah sektor pertanian jauh tertinggal. Tingkat upah tenaga kerja di Propinsi Lampung menggunakan landasan SK Gubernur tentang petapan upah minimum regional. Data perkembangan tingkat upah minimum regional Lampung dapat dilihat pada Gambar 2.

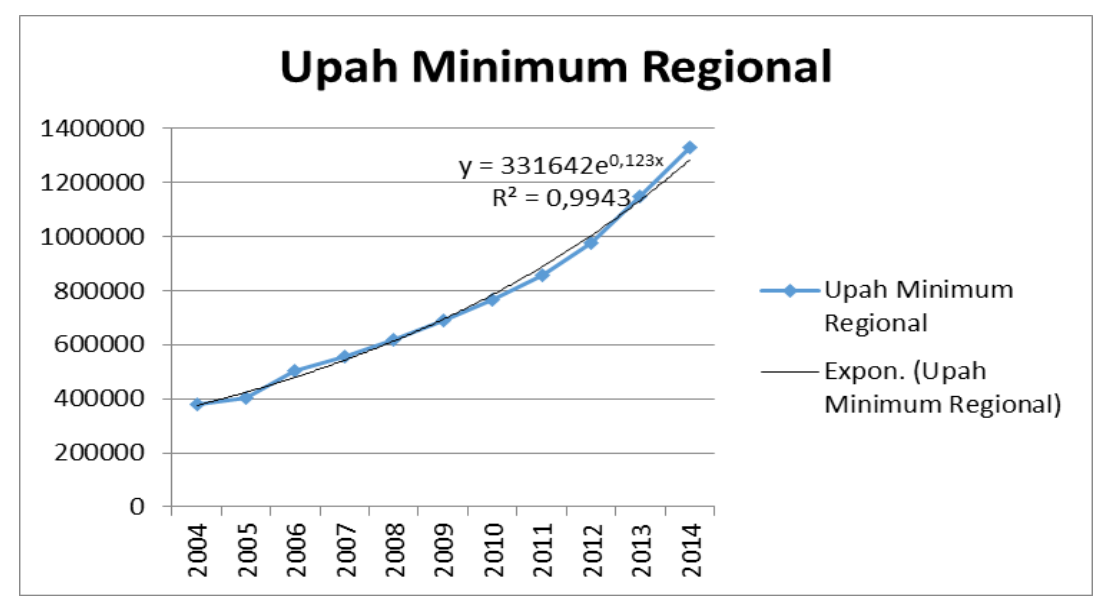

Gambar 2. Upah minimum regional Lampung dari tahun 2004-2014

Pada Gambar 2 dapat dilihat perkembangan upah minimum regional Lampung dari tahun 2004-2014. Dengan laju rata-rata peningkatan sebesar 13,5\% upah minimum regional (UMP) Lampung berupaya untuk dapat memenuhi kebutuhan hidup minimum. Apabila kita kalkulasi dalam upah harian, tingkat UMP per hari menjadi sebesar Rp 53.200,- atau setara 6,2 $\mathrm{kg}$ beras (beras medium asalan Rp 8.500/kg). UMP menjadi dasar penetapan upah tenaga kerja sektor formal secara nasional. Bagaimana kondisinya dengan sektor pertanian perdesaan yang diperlakukan secara informal?

Besaran tingkat upah pekerja sektor pertanian informal dihargai lebih rendah dari UMP harian Lampung. Berbagai daerah kabupaten di Lampung masih banyak yang memberikan besaran upah tenaga kerja pertanian pada kisaran Rp 35.000 - 45.000/hari. Kondisi ini menunjukkan bahwa nilai tukar upah pekerja pertanian formal hanya setara 4,1-5,2 kg beras. Apabila dibandingkan dengan konsisi upah buruh perkebunan pada jaman penjajahan Belanda pada situasi tahun 1930 setara 4,2 $\mathrm{kg}$ beras (Siagian, 2013), maka sungguh pembangunan pertanian menjadi ironi.

Berdasarkan perbandingan nilai Indeks Diterima Petani sebesar 111,82 : Indeks Dibayar Petani 109,86 pada Februari 2014 menunjukkan selisih sangat tipis. NTP (Nilai Tukar 
Petani) adalah perbandingan indeks yang diterima petani dan indeks yang harus dibayar petani. Pada Juli 2014 tercatat NTP (Nilai Tukar Petani) sebesar 103,99. Hal ini menjadi indikator rendahnya nilai tambah produk pertanian Lampung. Walaupun secara matematis petani masih menerima lebih tinggi dari yang harus dibayarkan, namun karena produk pertanian berupa raw material yang diperdagangan dalam jangka pendek sangat beresiko menghadapi fluktuasi harga, bulky, dan musiman maka bagian petani dapat tergerus semakin kecil akibat resiko yang timbul.

Pada sisi lain, masyarakat pertanian disadarkan pada kondisi penurunan luas kepemilikan lahan. Konversi dan alih fungsi lahan pertanian untuk pembangunan sektor industri dan perumahan tampak jelas dari penurunan luas lahan garapan mencapai 19,50\% dalam sepuluh tahun terakhir. Meskipun terdapat realita bahwa penguasaan asset lahan pertanian skala besar (>30 ha) tumbuh mencapai 18,57\% (BPS, 2013). Kondisi ini menjadi ironi bila ternyata redistribusi lahan menuju konglomerasi bagi para pemodal dan sebaliknya akan meningatkan jumlah petani gurem bagi petani kecil yang akses kepemilikan lahannya makin sempit dan terbatas.

\section{Kemiskinan Perdesaan}

Perdesaan menghadapi persoalan kemiskinan yang kompleks. Penduduk miskin di Lampung pada tahun 2013 mencapai 4.216 .518 orang. Lebih dari 83\% (atau sebanyak 3.515.663) penduduk miskin Lampung merupakan masyarakat yang berada di perdesaan, sisanya berada di Kota Bandar Lampung dan Metro (BPS Lampung, 2013). Penduduk miskin berdasarkan kabupaten di Lampung dapat dilihat pada gambar berikut.

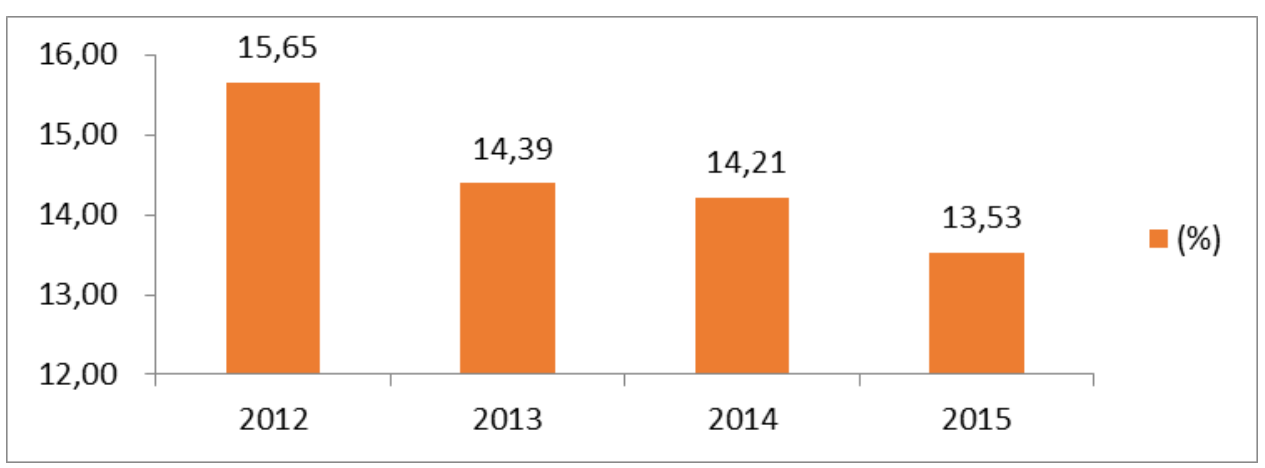

Gambar 3. Perkembangan penduduk miskin Lampung 2012-2015

Sumber: BPS Lampung, 2016

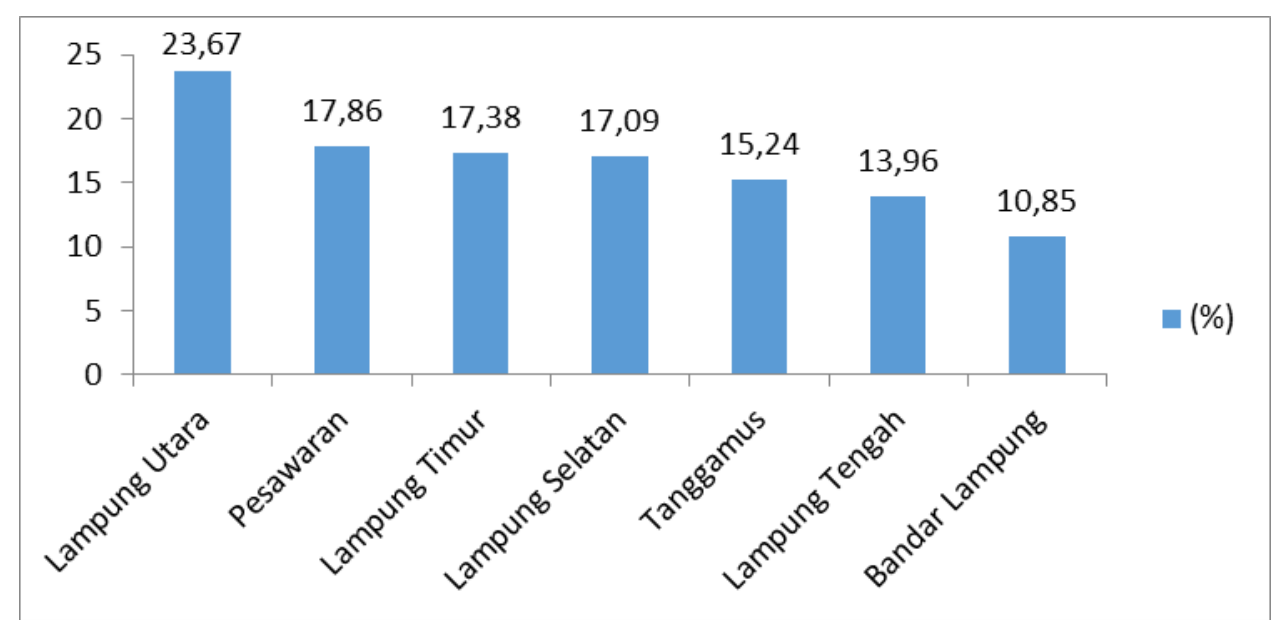

Gambar 4. Sebaran penduduk miskin per kabupaten di Lampung tahun 2015

Sumber: BPS Lampung, 2016

Pada Gambar 2 dapat dilihat bahwa, penduduk miskin perdesaan menjadi fakta tantangan pembangunan yang sangat penting. Dengan jumlah mencapai 4.216.518 jiwa penduduk miskin, 
artinya lebih dari 54\% dari penduduk Lampung (7.767.312) menjadi target pengentasan kemiskinan di Lampung.

Kompleksitas persoalan kemiskinan tidak hanya membahas angka jumlah dan persentase penduduk miskin. Adalah penting untuk melihat dari perspektif lain. Perspektif yang perlu diperhatikan adalah tingkat kedalaman dan keparahan kemiskinan. Perspektif dimensi pengukuran kemiskinan secara empiris menggunakan terminologi kedalaman (Depth of poverty) dan keparahan (Severity of poverty) kemiskinan (Yudhoyono dan Harniati, 2004; Nanga, 2006; dan Foster et al., 1984 dalam Haryono (2008)). Depth of poverty menggambarkan tingkat kedalaman kemiskinan di suatu wilayah yang diukur dengan poverty gap index (P1). Severity of poverty menunjukkan kepelikan kemiskinan di suatu wilayah, yang merupakan rata-rata dari kuadrad kesenjangan kemiskinan (squared poverty gaps/P2). Oleh karena itu, kebijakan pengurangan jumlah penduduk miskin juga terkait dengan bagaimana mengurangi tingkat kedalaman dan keparahan kemiskinan. Penurunan nilai kedua indeks ini mengindikasikan bahwa ada peningkatan pengeluaran penduduk miskin yang semakin mendekati garis kemiskinan. Selain itu ketimpangan pengeluaran penduduk miskin juga menjadi semakin kecil. Nilai Indeks Kedalaman Kemiskinan (P1) dan Indeks Keparahan Kemiskinan (P2) di daerah perdesaan relatif lebih tinggi dibandingkan nilai indeks di daerah perkotaan (BPS, 2013). Kondisi indeks kedalaman dan keparahan di Lampung 2011-2013 dapat dilihat pada tabel berikut.

Tabel 1. Indeks kedalaman dan keparahan kemiskinan Lampung 2011 s.d. 2013

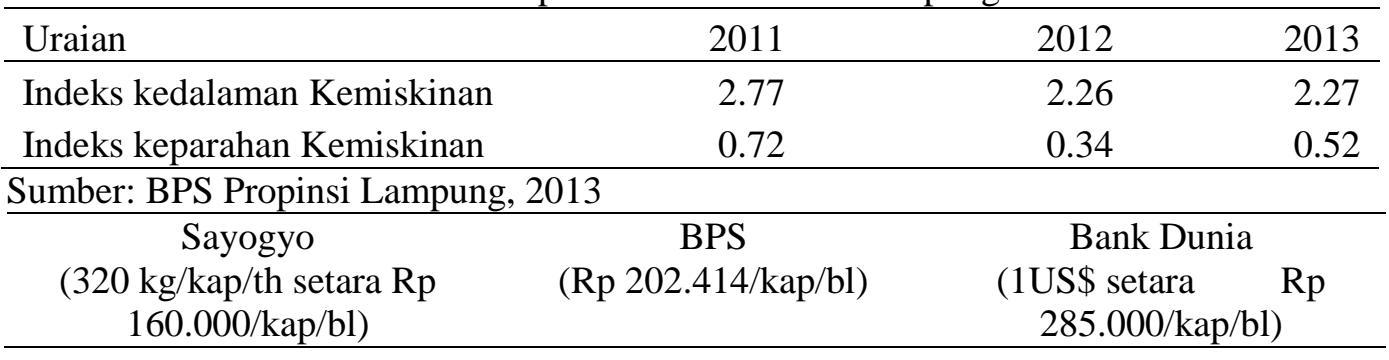

Berdasarkan Tabel 1 dapat dilihat bahwa nilai P1 (indeks kedalaman kemiskinan) di Lampung menunjukan penurunan dari tahun 2011-2012, namun meningkat tipis pada tahun 2013. Hal ini berarti, pada situasi tahun 2012 tingkat pendapatan penduduk mengalami peningkatan lebih tinggi mendekati garis kemiskinan. Namun pelambatan terjadi pada tahun 2013, sehingga situasi tahun 2013 menggambarkan kondisi bahwa tingkat pendapatan masyarakat tidak mengalami peningkatan, bisa jadi sebagai akibat turunnya daya beli akibat tingkat inflasi. Inflasi tahun 2013 Lampung mencapai 4,30\% meningkat dari 4,24\% pada tahun 2012. Inflasi tahun 2013 mencapai 7,56\%. Inflasi yang tinggi menyebabkan turunnya daya beli masyarakat sehingga meningkatkan nilai Indeks keparahan kemiskinan (P2) yang terlihat mengalami peningkatan dari tahun 2012-2013.

Sementara itu, indikator distribusi (pemerataan) pendapatan masyarakat Lampung yang ditunjukkan oleh nilai Gini Rasio menunjukkan bahwa masyarakat Lampung memiliki ketimpangan distribusi pendapatan relatif lebih rendah dibandingkan nasional dengan nilai Gini Rasio sebesar 3,356 lebih kecil dari Indonesia $(0,413)$ berarti ketimpangan distribusi pendapatan masyarakat Lampung masuk kategori rendah. Gambaran ini merupakan indikasi bahwa distribusi pendapatan masayarakat Lampung pada posisi ketimpangan rendah. Lebih lanjut dapat diartikan bahwa penduduk miskin di Lampung menerima bagian pendapatan relatif tidak berbeda antar sesama dan tidak timpang terpaut jauh dengan masyarakat golongan pendapatan yang lebih tinggi.

Secara nasional, fakta bahwa sektor pertanian sebagai sektor utama dalam struktur ekonomi Indonesia dapat dilihat dari kontribusi sektor pertanian mencapai > 35\% dalam PDB Nasional. Namun angka kemiskinan di Indonesia masih tinggi, mencapai 28,28 juta jiwa $(14,32 \%)$, dengan konsentrasi 10,5 juta jiwa merupakan masyarakat miskin perkotaan dan 17,7 
juta jiwa masyarakat perdesaan. Kemiskinan perdesaan menjadi representasi tidak optimalnya kinerja pembangunan pertanian. Pertanian perdesaan minim memberikan tingkat pendapatan dan kesejahteraan yang memadai bagi masyarakatnya.

Kemiskinan struktural perdesaan tidak terlepas dari terbatasnya akses masyarakat perdesaan dalam kepemilikan lahan. Kondisi ini dapat dilihat dari peningkatan Rumah Tangga Pertanian (RTP) dengan akses lahan $<0,25$ ha mengalami peningkatan $>33 \%$ dalam kurun 10 tahun terakhir.

Tabel 3. Rumah Tangga Pertanian di Indonesia, 2013

\begin{tabular}{lccr}
\hline \multirow{2}{*}{ Katagori } & \multicolumn{2}{c}{ Tahun } & Perubahan \\
\cline { 2 - 4 } & 2003 & 2013 & $(\%)$ \\
\hline RT usaha pertanian pengguna & & & \\
lahan & $30,419,582.00$ & $25,751,266.00$ & 18.13 \\
RT usaha pertanian gurem & $19,015,051.00$ & $14,248,870.00$ & 33.45 \\
\hline
\end{tabular}

Ironi RTP gurem mengalami kenaikan hampir dua kali lipatnya. Kondisi ini menunjukkan bahwa RTP gurem mendominasi wajah pertanian di Indonesia. Lebih dalam lagi berarti juga bahwa petani dengan penguasaan lahan kurang dari 0,25 ha dengan kondisi skala usaha yang tidak efisien, produktivitas rendah, tingkat pendapatan dan kesejahteraan rendah. Pertanian skala rakyat memberikan tingkat pengembalian pendapatan yang tidak memadai, menyebabkan mereka mengalami keterbatasan dalam mengakses input-input produktif bagi pertaniannya. Pada sisi lain mereka harus memenuhi kebutuhan hidup keluarganya dengan pendapatan yang rendah. Daya beli masyarakat pertanian menurun, dapat dilihat dari indeks niai tukar petani yang cenderung terus menurun (Februari 2014 NTP $=103$ ). Petani perdesaan juga menghadapi keterbatasan akses modal dari lembaga keuangan karena rumitnya prosedur dan prasyarat jaminan yang sulit. Kompleksitas pertanian rakyat bermuara pada kemiskinan.

Apalagi bagi masyarakat pertanian yang tidak memiliki lahan, mereka sebagai buruh tani. Mereka menerima tingkat upah yang sangat rendah dibandingkan sektor lain (Fitriani et al. 2015). Tingkat upah buruh pertanian pada saat ini rata-rata bila dikalkulasi menggunakan Upah regional minimum Lampung sebesar Rp 1.581.000,-/bulan atau setara Rp 65.875,-/hari. Dengan kata lain, kondisi buruh pertanian saat ini tidak lebih baik kalau tidak dapat dikatakan buruk dibandingkan pada masa kolonial. Kemerdekaan selama 72 tahun belum mampu menunjukkan pembangunan pertanian dapat secara komprehensif menjawab keterpurukan masyarakat perdesaan masih dalam menghadapi kondisi yang tidak lebih baik dari masa penjajahan. Kondisi ini mendorong mereka melakukan urbanisasi untuk mencari kehidupan yang lebih baik. Namun karena prasyarat keterampilan tenaga kerja dari perdesaan yang tidak memenuhi kualifikasi tenaga kerja migrant kota menyebabkan mereka mengisi ruang tenaga kerja informal yang berpenghasilan kurang. Akibat lanjutnya menyebabkan kemiskinan perkotaan meningkat dengan kata lain kota sebagai muara migrasi masyarakat miskin perdesaan. Kondisi ini dapat dilihat dari penduduk miskin yang ada di kota Bandar Lampung masih mencapai lebih dari $10 \%$.

Pembangunan pertanian bertujuan untuk meningkatkan kesejahteraan masyarakat pertanian melalui perbaikan sistem produksi, infrastruktur, inovasi dan adopsi teknologi serta kelembagaan pertanian yang solid. Namun kondisi tersebut secara struktural belum secara terintegrasi diselesaikan melalui keberpihakan kebijakan anggaran pertanian yang berpihak dan komprehensif. Fakta menunjukkan bahwa alokasi anggaran untuk sektor pertanian dalam 5 tahun terakhir $<4 \%$, dengan $>50 \%$ merupakan belanja pegawai. Berarti belanja modal dalam sektor pertanian kurang dari 2\%. Kondisi tersebut berimplikasi pada rendahnya alokasi penelitian dan pengembangan bagi inovasi dan teknologi pertanian $(<0.02 \%)$ terkini. Padahal sektor input pertanian membutuhkan penemuan-penemuan baru varietas unggul yang memiliki produktivitas tinggi yang mampu beradaptasi dengan perubahan iklim, hemat air, tahan 
serangan OPT, berumur pendek, dan keunggulan spesifik lokasi lainnya melalui teknologi rekayasa genetika.

Pupuk-pupuk organik/hayati dengan teknologi terkini (nanoteknologi) yang mampu memperbaiki dan mengembalikan daya dukung lahan. Juga terobosan metode budidaya pertanian yang inherent dapat memperbaiki fungsi hidrologi dan ekologi. Terbatasnya anggaran sektor pertanian juga menyebabkan minimnya pembangunan infrastruktur pertanian seperti irigasi, jalan usahatani, jembatan, dan gudang, serta pasar produk pertanian. Pembangunan infrastruktur pertanian yang menjadi tugas pemerintah relatif absen dalam kurun 3 dekade terakhir. Akibatnya lahan-lahan produktif dengan pengairan irigasi banyak mengalami kerusakan, juga buruknya kerusakan wilayah hulu dan DAS yang tergerus menyebabkan kemampuan menyediakan air untuk budidaya pertanian tidak memadai. Lebih lanjut, alih fungsi lahan pertanian untuk peruntukan lain (pemukiman, industry, dll) dengan alasan pembangunan menjadi kenyataan pahit makin berkurangnya lahan pertanian produktif. Ratarata terjadi pengalihan lahan produktif di Indonesia mencapai 106.000 ha per tahun.

Pada sisi lain, alokasi anggaran untuk peningkatan SDM petani dan pendukung pertanian sangat kecil. Pasca reformasi, praktis pendampingan petani melalui penyuluhan intensif absen. Padahal SDM pertanian terutama skala rakyat menghadapi persoalan peningkatan kapasitas akses teknologi. Pendampingan transfer teknologi terhadap masyarakat pertanian melalui penyuluhan secara terstruktur dan berkelanjutan masih sangat kurang. Kondisi ini tidak dapat dibiarkan. Upaya pemberdayaan petani melalui pendampingan penyuluhan secara intensif menjadi keniscayaan dalam upaya peningkatan produktivitas pertanian.

Pada prinsipnya, kemiskinan secara ekonomi sebagaimana tersebut di atas dapat diatasi dengan pemenuhan kebutuhan mendasar melalui penciptaan lapangan kerja yang berbasis kerakyatan, pengembangan agribisnis, dan agroindustri (bioindustri perdesaan) dengan basis sumberdaya lokal, pembangunan infrastruktur, dan penguatan lembaga-lembaga sosial masyarakat (Daryanto dan Hafizrianda, 2010). Implementasi praktik kebijakan pengentasan kemiskinan tentu saja tidak sesederhana itu. Fitriani dan Haryono (2011) pada kasus yang dihadapi petani tebu rakyat menyebutkan perlunya berbagai upaya dilakukan antara lain: melalui penguatan kelembagaan petani tebu rakyat dan memperbaiki sinergi dan kinerja kerjasama kemitraan dengan pabrik gula. Tentu saja persoalannya tidak akan sederhana. Perlu kerja keras dan langkah perjuangan panjang untuk memastikan segenap stakeholders industri gula, termasuk di dalamnya adalah petani tebu, PG, asosiasi pedagang gula, pemangku kekuasaan, dan pihak-pihak lain yang terlibat secara bertanggung jawab, terencana, sistematis, dan terstruktur memperbaiki kondisi kesejahteraan petani tebu rakyat sebagai mitra sejajar.

Kemiskinan penduduk di Lampung tidak dapat dilepaskan dari upaya peningkatan produktivitas pertanian. Pada sisi lain, sektor pertanian mendapatkan perhatian minimum, minus alokasi anggaran pembangunan, juga pembiaran dan marginalisasi yang menyebabkan pembangunan dan pengembangan sektor pertanian mengalami stagnasi kalau tidak dikatakan mundur (Fitriani et al. 2014).

Pembangunan wilayah pedesaan dengan prinsip orientasi pada ekonomi kerakyatan dilakukan ke arah kegiatan-kegiatan ekonomi yang berlangsung dengan melibatkan partisipasi semua anggota masyarakat, hasil-hasilnya untuk masyarakat, serta pelaksanaan kegiatan ekonomi di bawah pimpinan dan pengawasan masyarakat. Berdasarkan prinsip tersebut, pengembangan pertanian perlu terus dikembangkan dengan tujuan untuk meningkatkan pendapatan dan kesejahteraan masyarakat melalui penciptaan kesempatan kerja yang melibatkan masyarakat perdesaan seluas-luasnya.

Daryanto dan Hafizrianda (2010) menjelaskan bahwa terjadinya integrasi ekonomi yang kuat, menyeluruh, dan berkelanjutan diantara semua sektor ekonomi menjadi kunci pembangunan ekonomi. Salah satu model yang dapat secara jelas memaparkan interaksi antarpelaku ekonomi adalah model input output (I-O). Model I-O dapat menentukan besaran aliran keterkaitan antar sektor. Secara jelas interaksi tersebut terjadi di pasar input. Pengaruh interaksi ekonomi dikelompokkan dalam tiga jenis, yaitu: (1) pengaruh langsung (direct effect); (2) pengaruh tidak langsung (indirect effect); dan (3) pengaruh total. 


\section{Simpulan}

Potret pertanian Lampung didominasi oleh pertanian perdesaan yang menghadapi persoalan sangat kompleks. Kompleksitas problem masyarakat pertanian merupakan resultanse dari keterbatasan yang masih dihadapi petani dalam mengakses sumberdaya modal, lahan, teknologi, dan kelembagaan. Lebih lanjut bermuara pada kemiskinan structural.

Kunci bekerjanya kebijakan pembangunan pertanian perdesaan berkelanjutan adalah terjadinya sinergi dalam mengatasi hambatan-hambatan meliputi: kondisi agro-klimat lokal, teknologi spesifik lokasi, ketersediaan biomasa Insentif ekonomi, pasar produk, akses informasi, penguasaan lahan, kelembagaan, penyuluhan, dan kendala politik.

\section{Daftar Pustaka}

BPS Propinsi Lampung. 2013. Lampung Dalam Angka. Bandar Lampung

-------. 2013. Statistik Daerah Lampung. Bandar Lampung

BPS Indonesia. 2005. Statistik Indonesia. Biro Pusat Statistik. Jakarta

Daryanto, Arief dan Hafizrianda, Yundy. Model-Model Kuantitatif untuk Perencanaan Pembangunan Daerah. Konsep dan Aplikasi. PT Penerbit IPB Press. Bogor. 346 hal.

Fitriani, Sutarni, Hanung Ismono, and Dwi Haryono. 2014. "Kinerja Sub Sektor Tanaman Pangan Pada Sektor Pertanian Lampung.” In Prosiding Seminar Nasional Kedaulatan Pangan Dan Pertanian, eds. Jangkung Handoyo Mulyo Sugiyarto Muslimin et al. Yogyakarta: Jurusan Sosial Ekonomi Pertanian Faperta UGM, 212-20.

Fitriani, Sutarni, Hanung Ismono, and Dyah Aring Hepiana Lestari. 2015. "Masa Depan Tenaga Kerja Sektor Pertanian.” In INOVASI SAINS DAN TEKNOLOGI UNTUK KETAHANAN PANGAN DAN KEMANDIRIAN ENERGI, eds. Yusnita et al. Bandar Lampung: LPPM Universitas Lampung, 319-34.

Gustiawan, Irvan. 2010. Dampak Agroindustri Jagung Terhadap Pengembangan Wilayah Propinsi Lampung. Fakultas Pertanian Universitas Lampung. Bandar Lampung.

Hamidi, Hirwan. 2010. Dampak Pengembangan Sektor Pertanian Pangan terhadap Output, Nilai Tambah NTB: Pendekatan I-O. Jurusan Sosek Fakultas Pertanian Unram.

Haryono, Dwi. 2008. Dampak Industrialisasi Pertanian terhadap Kinerja Sektor Pertanian dan Kemiskinan Perdesaan: Model CGE Recursive Dynamic. Disertasi. Sekolah Pascasarjana IPB. Bogor.

Hernandez, Gustavo. 2008. Building a Financial Social Accounting Matrix for Columbia. Applied Economic Studies, Vol. 26, No. 3, pp 7-26, 2008. http://www.ssrn.org

Isard, W., I.J. Azis, M.P. Drennan, R.E. Miller, S. Saltzman and E. Thorbecke. 1998. Methods of Interregional and Regional Analysis. Ashgate Publishing Company. Brookfield Vermont 05036.

Kasiyati, Sri dan Purbayu Budi Santosa. 2010. Analisis Dampak Subsidi Harga Pupuk Terhadap Output Sektor Produksi dan Tingkat Pendapatan Rumahtangga di Jawa Tengah: Pendekatan I-O dan SNSE. Jurnal Organisasi da Manajemen. Vol. 6. No. 1, Maret 2010.

Mosher, AT. 1991. Menggerakkan dan Membangun Pertanian. Syarat-syarat Pokok Pembangunan dan Modernisasi. C.V. Yasaguna. Jakarta. 251 hal

Todaro, Michael P. 2000. Pembangunan Ekonomi Dunia Ketiga. Penerbit Erlangga. Jakarta --------. 2006. Teori Ekonomi Pembangunan. Penerbit Erlangga. Jakarta

Novita, Desi, Rahmanta, dan Kasyful Mahalli. 2009. Dampak Investasi Sektor Pertanian terhadap Perekonomian Sumatera Utara: Pendekatan I-O. Jurnal Perencanaan dan Pembangunan Wilayah. Vol 4. No. 3. April 2009.

Putra, Dody Yuli. 2011. Peranan Sektor Perikanan dalam perekonomian dan Penyerapan Tenaga Kerja di Indonesia: Analisis I-O. Pascasarjana Universitas Andalas. Padang.

JoFSA Vol. 1, No. 2, Oktober 2017: 43-52 
Rismanto, 2008. Dampak Pengembangan Komoditas Karet terhadap Perekonomian Wilayah Kabupaten Banjar. Tesis Pasca Sarjana Universitas Lambung Mangkurat. Pontianak.

Sinaga, Bonar M dan Alim, Moch Rum. 2005. Keterkaitan Sektor Ekonomi dan Distribusi Pendapatan di Jawa: Pendekatan SAM. Jurnal Soca Universitas Udayana. Denpasar. Sukanto, Dimas Gadang Tattaqun. 2011. Peranan Sektor Pertanian terhadap Perekonomian Jawa Tengah: Pendekatan I-O. Jurusan Ilmu Ekonomi dan Studi Pembangunan. FE Universitas Diponegoro. Semarang. 